\title{
Effects on fertilization of rabbits of insemination with ejaculates treated with PG-dehydrogenase and antisera to PGE-2 and PGF-2 $\alpha$
}

\author{
W. Schlegel, B. Fischer*, H. M. Beier* and H. P. G. Schneider \\ Universitätsfrauenklinik, Domagkstrasse, 11, D-4400 Münster, and *Abteilung Anatomie und \\ Reproduktionsbiologie, Medizinische Fakultät, RWTH Aachen, Melatener Strasse 211, \\ D-5100 Aachen, Federal Republic of Germany
}

\begin{abstract}
Summary. PGE-2 and PGF- $2 \alpha$ in rabbit semen were selectively inactivated by incubation with antisera, or most of the seminal prostaglandins were transformed into biologically inactive 15-keto-prostaglandins by prostaglandin-15-hydroxydehydrogenase (PG-15-HDH). These treated ejaculates were vaginally inseminated. Compared to the controls ( 738 eggs of which $94 \%$ were fertilized) a dose-dependent reduction of the fertilization rate was observed with the anti-PGF- $2 \alpha$-treated ejaculates. A nonuniformly, but statistically significantly reduced fertility was found in the other 2 treatment groups. After incubation with higher doses of PG-15-HDH, some fertilization was accomplished with ejaculates showing an extremely weak forward progression or immotile spermatozoa. An improvement in sperm motility, however, was observed in ejaculates treated with antiserum to PGF- $2 \alpha$. Seminal prostaglandins may not exclusively affect sperm motility. The observed influences on the fertilization rate after treatment of spermatozoa with antisera to PGE-2 and PGF-2 $\alpha$ or PG-15$\mathrm{HDH}$ suggest that these are local effects in the female genital tract.
\end{abstract}

\section{Introduction}

Studies on human spermatozoa have established that prostaglandin (PG) F-2 $\alpha$ exerts an inhibitory effect on sperm motility in vitro (Cohen, Colin, Golimbu \& Hotchkiss, 1976; Didolkar \& Roychowdhury, 1980; Schlegel, Rotermund, Färber \& Nieschlag, 1981). However, systemically applied PGF-2 $\alpha$ enhances sperm transport in vivo (Chang, Hunt \& Polge, 1973; Spilman, Finn \& Norland, 1973; Edqvist, Einarsson \& Gustafsson, 1975) and other prostanoids are also believed to be involved in the fertilization process (Mandl, 1972; Poyser, 1974).

Prostaglandins are powerful agents for stimulating smooth muscles. This action might be the underlying mechanism for the acceleration of egg transport, demonstrated by Chang et al. (1973) and Lehmann, Hobohm, Kerf, Diedrich \& Krebs (1981), by modifying the haemodynamic status of the target tissues (Karim, 1972). High doses of PGF- $2 \alpha$ altered blood flow through the reproductive tissues of rabbits and monkeys (Kirton, Kimball \& Porteus, 1976). Gamete transport in the female genital tract is the first step in the process of normal fertilization, but the special contribution of seminal prostaglandins to this process is still unknown. We have, therefore, attempted to evaluate whether the metabolism of prostaglandins in the ejaculate has any influence on the fertilization rate. 


\section{Materials and Methods}

\section{Animals and treatment with prostaglandin antisera}

A total of 88 sexually mature rabbits of mixed breed and 9 bucks of proven fertility were used. The does had been caged individually for at least 21 days in a controlled environment with $14 \mathrm{~h}$ light/24 h. Semen was collected with an artifical vagina (Adams, 1962). All ejaculates were examined immediately after collection. Only those with high initial sperm motility were used. Pooled semen samples were diluted $1: 2$ with a diluent ( $\mathrm{pH} 7.6$ ) containing $360 \mathrm{~mm}$-Tris, $33.3 \mathrm{~mm}$ glucose, $113.7 \mathrm{mM}$-citric acid, and $6 \%(\mathrm{v} / \mathrm{v})$ dimethylsulphoxide. Egg yolk, penicillin, and streptomycin were added to give a final concentration of $5 \%(\mathrm{v} / \mathrm{v}), 0.01 \%(\mathrm{w} / \mathrm{v})$, and $0.05 \%$, respectively. Samples of $0.5 \mathrm{ml}$ per doe were used for artificial insemination into the vagina. All diluted ejaculates were incubated at room temperature for $15 \mathrm{~min}$ before insemination under identical conditions for all experiments. The semen samples were scored at $\times 100$ magnification for sperm motility as vigorously progressive, weakly progressive, with pendular movement, weak pendular movement or immotile.

The does were primed with a single subcutaneous injection of 100 i.u. PMSG (Seragon: Ferrin, Kiel, West Germany) 3 days before insemination. Ovulation was induced by intravenous injection of 75 i.u. hCG (Prolan: Bayer, Leverkusen, West Germany). The rabbits were killed by an intravenous injection of pentobarbitone sodium, $60 \mathrm{mg} / \mathrm{ml}$ (Nembutal: Ceva, Bad Segeberg, West Germany), $28 \mathrm{~h}$ after artificial insemination. The genital tract was excised and each oviduct was flushed with $3 \mathrm{ml} 0.9 \%(\mathrm{w} / \mathrm{v}) \mathrm{NaCl}$ solution. The eggs were examined microscopically to determine the numbers fertilized by counting the 2-cell and 4-cell embryos. The does in Group 1 comprised 26 control animals. They were inseminated with diluted ejaculates $\left(174 \pm 73 \times 10^{6}\right.$ spermatozoa $\left./ \mathrm{ml}\right)$ without any additive other than $\mathrm{NAD}^{+}$. Group 2 does were inseminated with ejaculates from the same pool, but treated for $15 \mathrm{~min}$ at $30^{\circ} \mathrm{C}$ with different amounts of undiluted antisera to PGF- $2 \alpha$ $(\mathrm{N}=21)$. Group 3 does were inseminated with ejaculates treated with antiserum to PGE-2 $(\mathrm{N}=$ 15). The antisera were identical to those described by Schlegel, Wenk, Dollinger \& Raptis (1977). The does in Group $4(\mathrm{~N}=31)$ were inseminated with ejaculates which were preincubated with different amounts of prostaglandin-15-hydroxydehydrogenase (PG-15-HDH) and $\mathrm{NAD}^{+}$ $(1 \mathrm{mmol} / \mathrm{l})$ for at least $15 \mathrm{~min}$ before insemination.

The incubation of ejaculates with PG-15/HDH, but no cofactor, did not influence the motility of spermatozoa within $15 \mathrm{~min}$. For control experiments the antisera and the PG-15-HDH were labelled with radioiodine $\left({ }^{125} \mathrm{I}\right)$ as described by Stadil \& Rehfeld (1972). There was no radioactivity detectable in the upper reproductive tract within $4 \mathrm{~h}$, using tissue homogenates of endometrium as well as endosalpinx. The radioactively labelled material remained predominantly in the vaginal tissue (unpublished data). The PG-15-HDH was purified by the slightly modified procedure of Schlegel \& Greep (1975).

\section{Analysis of semen samples}

Prostaglandins E-2 and F-2 $\alpha$ were estimated by radioimmunoassay (Schlegel et al., 1977). Samples were acidified with $1 \mathrm{~N}-\mathrm{HCl}$ and extracted with ethyl acetate. The extracts were applied to columns of silicic acid BIO-Sil A, 100-200 mesh (BIO-Rad, Richmond, U.S.A.) and chromatographed for PGE-2 and PGF- $2 \alpha$ concentrations (Jaffe \& Behrman, 1974). The overall recovery of added PGE-2 and PGF- $2 \alpha$ was $70-75 \%$. All samples were analysed in duplicate. Validation of the assay was based on the quantitative recovery of various amounts of PGE-2 or PGF- $2 \alpha$ added to seminal and blood plasma $(0 \cdot 1-10 \mathrm{ng} / \mathrm{ml} ; r=0.95 ; n=11)$. The sensitivities of the assays were $15 \mathrm{pg} /$ tube and the lower limits of the assays were $60 \mathrm{pg} / \mathrm{ml}$.

The cross-reactivity of antiserum to PGE- 2 was below $0.1 \%$ for PGF- $2 \alpha$, PGI-2, PGD-2, 15 - 
keto-PGE-2, 15-keto-PGF-2 $\alpha$, 13,14-dihydro-15-keto-PGE-2, 13,14-dihydro-15-keto-PGF-2 $\alpha, 19$ hydroxy-PGE-2, and 19-hydroxy-PGF- $2 \alpha, 70 \%$ for PGA-2 and $50 \%$ for PGE-1. The antibody to PGF- $2 \alpha$ was highly specific. The cross-reactivity was below $0 \cdot 1 \%$ for all available prostaglandins. The cross-reactivity data are expressed as the ratio of the prostaglandin concentration to the crossreacting substance concentration at $50 \%$ inhibition of maximum binding. The inter- and intraassay coefficients of variations were 10.5 and $13.0 \%$ for PGE-2 and 7.0 and $9.8 \%$ for PGF- $2 \alpha$, respectively. The 13,14-dihydro-15-keto-metabolites were measured by the methods of Schlegel, Urdinola \& Schneider (1982) and Urdinola, Schlegel, Schneider \& Nieschlag (1981).

ATP was measured with the luciferin-luciferase assay (Brooks, 1970) and glutathione according to Tietze (1969).

Student's unpaired $t$ test was used to evaluate any statistical significances resulting from treatment.

\section{Results}

As shown in Table 1, prostaglandin metabolites were not detectable whereas PGE-2 and PGF- $2 \alpha$ were present in values about $0.1 \%$ of those in human semen (Schlegel et al., 1981). ATP concentrations were exclusively detectable in the cells of all ejaculates. The absence of ATP in the seminal plasma could be used as index for unruptured spermatozoa after treatment. Glutathione was measurable in the cells and in the seminal plasma of all ejaculates in the same concentration ranges. The treatment with antisera or $\mathrm{PG}-15-\mathrm{HDH}$ did not change the ratio of oxidized versus reduced glutathione. Throughout all experiments, the spermatozoa were vigorously motile before insemination. A total of 738 eggs was recovered from the control animals of which $697(94 \%)$ were fertilized. The results for inseminations with treated ejaculates are shown in Table 2 . The fertilization rate was dose-dependently reduced when the concentration of antiserum to PGF- $2 \alpha$ exceeded $15 \mu \mathrm{l}$ per inseminate. The overall percentage of fertilization was statistically significantly reduced $(P<0.05)$ when compared to the control group. However, careful examination of the spermatozoa failed to detect any loss of motility.

Table 1. Analysis of rabbit ejaculates

\begin{tabular}{lc}
\hline PGE-2 & $42.2 \pm 29.6 \mathrm{ng} / \mathrm{ml}$ \\
PGF-2 $\alpha$ & $3.7 \pm 3.1 \mathrm{ng} / \mathrm{ml}$ \\
PGE-2 metabolite & $<10 \mathrm{pg} / \mathrm{ml}$ \\
PGF-2 $\alpha$ metabolite & $<10 \mathrm{pg} / \mathrm{ml}$ \\
ATP & $1.73 \pm 2.34 \mu \mathrm{mol} / 10^{8}$ \\
& \multicolumn{2}{c}{$\mathrm{spermatozoa}$} \\
Glutathione, total & $147.3 \pm 70.6 \mathrm{ng} / \mathrm{ml}$ \\
No. of spermatozoa & $142.2 \pm 83.0 \times 10^{6} / \mathrm{ml}$ \\
\hline
\end{tabular}

Values are mean \pm s.d. for 28 ejaculates.

The treatments with antisera or PG-15-HDH did not change ATP or glutathione concentrations.

The addition of PGE-2 antiserum to the inseminates affected the sperm motility pattern slightly in Group 3 compared to the controls. The overall fertilization rate was statistically significantly reduced $(P<0.0005)$ but was not dose-dependent. Exposure to PG-15-HDH and cofactor led to a dramatic decrease in sperm motility (Table 2). However, fertilized eggs were recovered in all treatment groups. The overall reduction of the fertilization rate was statistically significant $(P<$ $0 \cdot 01)$ when compared to the control group, but there was no obvious dose-dependent effect. 
Table 2. Fertilization in rabbits after insemination of ejaculates treated with antiserum to PGF-2 $\alpha$ (Group 2), antiserum to PGE-2 (Group 3) or PG-15-hydroxydehydrogenase (Group 4)

\begin{tabular}{|c|c|c|c|c|c|c|c|c|}
\hline \multirow{2}{*}{ Group } & \multirow{2}{*}{$\begin{array}{c}\text { No. of } \\
\text { females } \\
\text { inseminated }\end{array}$} & \multirow{2}{*}{$\begin{array}{l}\text { Sperm conc. } \\
\left(\times 10^{6} / \mathrm{ml}\right)\end{array}$} & \multirow[b]{2}{*}{ Motility* } & \multirow{2}{*}{$\begin{array}{c}\text { Amount of test } \\
\text { substance } \\
(\mu 1) \text { per } \\
\text { inseminate }\end{array}$} & \multicolumn{3}{|c|}{ No. of eggs } & \multirow{2}{*}{$\begin{array}{c}\text { Fertilization } \\
(\%)\end{array}$} \\
\hline & & & & & Recovered & Unfertilized & Fertilized & \\
\hline \multirow[t]{6}{*}{2} & 3 & 197.5 & +++ & $0 \cdot 3$ & 46 & 6 & 40 & 87 \\
\hline & 3 & 197.5 & +++ & $2 \cdot 0$ & 49 & 1 & 48 & 98 \\
\hline & 3 & $140 \cdot 0$ & +++ & 15.0 & 115 & 5 & 110 & 96 \\
\hline & 6 & $140 \cdot 0$ & +++ & $30 \cdot 0$ & 141 & 60 & 81 & 57 \\
\hline & 3 & 197.5 & +++ & $100 \cdot 0$ & 34 & 22 & 12 & 35 \\
\hline & 3 & $75 \cdot 5$ & +++ & $150 \cdot 0$ & 74 & 46 & 28 & 38 \\
\hline Mean & 21 & & & & 459 & 140 & 319 & $69.5 \dagger$ \\
\hline \multirow[t]{4}{*}{3} & 3 & $282 \cdot 0$ & ++ & 15 & 50 & 27 & 23 & 46 \\
\hline & 6 & 155.0 & ++ & 30 & 129 & 47 & 82 & 64 \\
\hline & 3 & 282.0 & ++ & 100 & 39 & 21 & 18 & 46 \\
\hline & 3 & $282 \cdot 0$ & ++ & 150 & 47 & 14 & 33 & 70 \\
\hline Mean & 15 & & & & 265 & 109 & 156 & $58.9 \ddagger$ \\
\hline \multirow[t]{6}{*}{4} & 3 & $75 \cdot 5$ & + & 3 & 83 & 53 & 30 & 36 \\
\hline & 2 & $75 \cdot 5$ & + & 15 & 54 & 1 & 53 & 98 \\
\hline & 5 & $350 \cdot 0$ & $(+)$ & 30 & 68 & 64 & 4 & 6 \\
\hline & 7 & $210 \cdot 0$ & $(+)$ & 60 & 149 & 28 & 121 & 81 \\
\hline & 8 & $450 \cdot 0$ & - & 100 & 157 & 65 & 92 & 59 \\
\hline & 6 & $210 \cdot 0$ & - & 200 & 102 & 79 & 23 & 23 \\
\hline Mean & 31 & & & & 613 & 290 & 323 & $52 \cdot 7 \S$ \\
\hline
\end{tabular}

* Motility score: +++ vigorously progressive, ++ weak progressive, + pendular movement, $(+)$ weak pendular movement, - immotile.

† Control group $(\mathrm{N}=11): 287$ eggs were fertilized from a total of $299(96 \%$ fertilized).

$\ddagger$ Control group $(\mathrm{N}=6)$ : 140 eggs were fertilized from a total of $149(94 \%$ fertilized $)$.

$\S$ Control group $(N=9): 270$ eggs were fertilized from a total of $290(93 \%$ fertilized).

\section{Discussion}

PGF-2 $\alpha$ reduces the motility of human spermatozoa (Cohen et al., 1976; Schlegel et al., 1981). So far, this inhibition is difficult to understand, since there are no receptors for prostaglandins on or in spermatozoa (Schlegel et al., 1981). We could not find specific binding of PGE and PGF to sperm membranes as reported by Mercado, Villalobos, Dominguez \& Rosado (1978). The present results showed that treatment of rabbit ejaculates with antiserum to PGF- $2 \alpha$ did not affect sperm motility but inactivation of seminal prostaglandins by PG-15-HDH quickly produced immobilization of the spermatozoa. Consequently, prostaglandins other than PGF- $2 \alpha$ seem to be essential for sperm motility or for its maintenance in vitro. In vivo there was a dose-dependent reduction after treatment of the semen with antiserum to PGF- $2 \alpha$, and this is in accord with the findings of Spilman et al. (1973) who have demonstrated an improvement in the fertilization rate after systemic application of PGF- $2 \alpha$ to rabbits. However, our methodological approach of interference with components of the ejaculate itself seems to be more appropriate than systemic applications for evaluating the direct action of seminal PGF- $2 \alpha$ on the process of fertilization.

The present experiments also demonstrate that, even when spermatozoa were inseminated with biologically inactivated prostaglandins and had extremely weak forward progression if any at all, the fertilization rates are dramatically reduced but not to zero. This may be due to the presence of 
other prostaglandins in ejaculates (Kelly, 1981) which are not inactivated by the antisera and enzymes used or to prostaglandins derived endogenously from the female genital tract. For example, 19-hydroxyprostaglandins are known to be present in high quantities in the ejaculates of several species. A high sperm motility is not necessarily positively correlated with a high fertilization rate.

Prostaglandin receptors have been detected in the female reproductive tract (Armstrong, 1981; Bauknecht, Krahe, Rechenbach, Zahradnik \& Breckwoldt, 1981; Riehl \& Harper, 1981). Therefore it is possible that the effect of seminal prostaglandins on the female reproductive tract is mediated via these receptors. Since the vagina is capable of absorbing prostaglandins (Elder $\&$ Gordon-Wright, 1980), seminal prostaglandins could reach upper parts of the genital tract via a direct vascular route from the vagina to the uterus (Del Campo \& Ginther, 1972). Such prostaglandins could not only influence sperm motility but also affect the female reproductive tract and, in turn, contribute to gamete transport.

We thank Mrs Rosemarie Kusseler, Mrs Karin Pfleger, Mrs Maria Petuelli and Dr Ursula Mootz for valuable assistance. This work was supported by the Deutsche Forschungsgemeinschaft, special research programme on "Biologie und Klinik der Reproduktion" (Grant Schl 140/4-2), and by a grant of the Stifterverband für die Deutsche Wissenschaft to H.M.B.

\section{References}

Adams, C.E. (1962) Artificial insemination in rodents. In The Semen of Animals and Artificial Insemination, pp. 316-330. Ed. J. P. Maule. Commonwealth Agricultural Bureau, Farnham Royal.

Armstrong, D.T. (1981) Prostaglandins and follicular functions. J. Reprod. Fert. 62, 283-291.

Bauknecht, T., Krahe, B., Rechenbach, U., Zahradnik, H.P. \& Breckwoldt, M. (1981) Distribution of prostaglandin E-2 and prostaglandin F- $2 \alpha$ receptors in human myometrium. Acta endocr., Copenh. 98, 446-450.

Brooks, D.E. (1970) Observations on the content of ATP and ADP in bull spermatozoa using the firefly luciferase system. J. Reprod. Fert. 23, 525-528.

Chang, M.C., Hunt, D.M. \& Polge, C. (1973) Effect of prostaglandins on sperm and egg transport in the rabbit. Adv. Biosci. 9, 805-810.

Cohen, M.S., Colin, M.J., Golimbu, M. \& Hotchkiss, R.S. (1976) The effects of prostaglandins on sperm motility. Fert. Steril. 28, 78-84.

Del Campo, C.H. \& Ginther, O.J. (1972) Vascular anatomy of the uterus and ovaries and the unilateral effect of the uterus: guinea-pigs, rats, hamsters, and rabbits. Am. J. vet. Res. 33, 2561-2578.

Didolkar, A.K. \& Roychowdhury, D. (1980) Effects of prostaglandins E-1, E-2, F-1 $\alpha$, and F-2 $\alpha$ on human sperm motility. Andrologia 12, 135-140.

Edqvist, S., Einarsson, S. \& Gustafsson, B. (1975) Effect of PGF- $2 \alpha$ on sperm transport in the reproductive tract of the ewe. Acta vet. scand. 16, 149-151.

Elder, M.G. \& Gordon-Wright, A.P. (1980) Systemic absorption from the vagina of $\mathrm{PGE}_{2}$ administered for the induction of labor. Adv. Prostaglandin Thromboxane Res. 8, 1469-1476.

Jaffe, B.M. \& Behrman, H.R. (1974) Prostaglandins E, A and F. In Methods of Hormone Radioimmunoassay, pp. 19-34. Eds B. M. Jaffe \& H. R. Behrman. Academic Press, New York
Karim, S.M.M. (Ed.) (1972) The Prostaglandins. Wiley, New York.

Kelly, R.W. (1981) Prostaglandin synthesis in the male and female reproductive tract. J. Reprod. Fert. 62, 293-304.

Kirton, K.T., Kimball, F.A. \& Porteus, S.E. (1976) Reproductive Physiology: Prostaglandin-associated events. Adv. Prostaglandin Thromboxane Res. 2, 621625.

Lehmann, F., Hobohm, U., Kerf, H., Diedrich, K. \& Krebs, D. (1981) Influence of various prostaglandins on egg transport and cleavage of rabbit ova in vivo. Proc. 3rd Wld Congr. Human Reprod. Berlin West, Abstract vol., p. 223.

Mandl, J.P. (1972) The effect of prostaglandin E-1 on rabbit sperm transport in vivo. J. Reprod. Fert. 31, 263-269.

Mercado, E., Villalobos, M., Dominguez, R. \& Rosado, A. (1978) Differential binding of PGE ${ }_{1}$ and PGF $_{2 \alpha}$ to the human spermatozoa membrane. Life Sci. 22, 429436.

Poyser, N.L. (1974) Some aspects of prostaglandins in reproduction. Biochem. Soc. Trans. 2, 1196-1200.

Riehl, R.M. \& Harper, M.J.K. (1981) Changes in prostaglandin binding capacity to single oviductal smooth muscle cells after ovulation in the rabbit. Endocrinology 109, 1011-1016.

Schlegel, W. \& Greep, R.O. (1975) Prostaglandin 15hydroxy-dehydrogenase from human placenta. Eur. J. Biochem. 56, 245-252.

Schlegel, W., Wenk, K., Dollinger, H.C. \& Raptis, S. (1977) Concentrations of prostaglandin A-, E-, F-like substances in gastric mucosa of normal subjects and of patients with various gastric diseases. Clin. Sci. molec. Med. 52, 255-258.

Schlegel, W., Rotermund, S., Färber, G. \& Nieschlag, E. (1981) The influence of prostaglandins on sperm motility. Prostaglandins 21, 87-99. 
Schlegel, W., Urdinola, J. \& Schneider, H.P.G. (1982) Radioimmunoassay for 13,14-dihydro-15-ketoprostaglandin F-2 $\alpha$ and its application in normo- and anovulatory women. Acta endocr., Copenh. 100, 98104.

Spilman, C.H., Finn, A.E. \& Norland, J.F. (1973) Effect of prostaglandins on sperm transport and fertilization in the rabbit. Prostaglandins 4, 57-64.

Stadil, F. \& Rehfeld, J.F. (1972) Preparation of ${ }^{125}$ Ilabelled synthetic human gastrin-I for radioimmunoanalysis. Scand. J. clin. Lab. Invest. 30, 361-368.
Tietze, F. (1969) Enzymic method for quantitative determination of nanogram amounts of total and oxidized glutathione: applications to mammalian blood and other tissues. Analyt. Biochem. 27, 502 522.

Urdinola, J., Schlegel, W., Schneider, H.P.G. \& Nieschlag, E. (1981) Concentrations of 13,14-dihydro-15keto-prostaglandins E-2 (PGE2M) and F-2 $\alpha$ $(P G F 2 \alpha M)$ in plasma and cervical mucus during the cycle in ovulatory women. Acta endocr., Copenh. 97, Suppl. 243, Abstr. 71.

Received 29 July 1982 